\title{
Study of Calculation of Terrain Correction Using square pattern and sloped triangle Method in Karangsambung Area
}

\author{
Studi Perhitungan Koreksi Terrain dengan Komputasi Menggunakan Metode square pattern dan \\ sloped triangle pada Area Karangsambung
}

\author{
Salam R. A* , Wahyudi E. J, dan Setianingsih \\ Teknik Geofisika, Fakultas Teknik Pertambangan dan Perminyakan, Institut Teknologi Bandung, \\ Jalan Ganesa No 10, Bandung, 40132 \\ *Email: rafifabdussalam2@gmail.com
}

Submit: ; Revised: ; Accepted:

\begin{abstract}
Conventional assessments of terrain correction are carried out by laying out transparent paper containing the Hammer chart on topographic maps, then estimating the elevation for each compartment. But this procedure has disadvantages, the number of compartments are too small for area with many topographic variations, and there is a subjectivity from the observer in estimating the compartments height. This research aim to overcome these problems and get more accurate terrain correction value. In this research, estimation of terrain correction carried out usingsquare pattern and sloped triangle method. This method divides the area around the measurement point into a zone containing a square-shaped and triangle compartment. The research start with testing the program by using synthetic data to see the effect of rock bodies on terrain correction value. Then the program was applied to Karangsambung to see the topographic influence around Karangsambung on terrain correction. The program is then applied to gravity data, and the results are compared with calculations using the Hammer chart. Based on the synthetic data test, it was found that the value of terrain correction from a rock body measuring $10 x 10 \mathrm{~km}$ with a height difference of $1000 \mathrm{~m}$ from the station no longer significantly affects at the distance of $20 \mathrm{~km}$. The topography around Karangsambung in the form of South Seraju Ranges with altitude of $1000 \mathrm{~m}$ at distance of $2030 \mathrm{~km}$ gives effect of $0.05 \mathrm{mGal}$ on terrain correction, while the Quaternary Volcano with an altitude of $3000 \mathrm{~m}$ at distance of $30 \quad 40$ $\mathrm{km}$ gives effect of $0.1 \mathrm{mGal}$. The results of applying program at the gravity data show that the use of the square pattern method is able to correct errors from Hammer chart up to $3 \mathrm{mGal}$. The difference between the calculation of the two methods is getting bigger in the station located at slope area. It happens because estimation of the height difference in slope area is more difficult to do.
\end{abstract}

Keywordsi: Karangsambung, terrain correction, square pattern, sloped triangle

Abstrak: Perhitungan koreksi terrain secara konvensional dilakukan dengan menghamparkan kertas transparan berisi Hammer chart di atas sebuah peta topografi, kemudian ketinggian setiap kompartemen diestimasi. Prosedur ini memi- liki kelemahan, yaitu jumlah kompartemen yang relatif sedikit untuk daerah dengan variasi topografi yang besar, dan adanya subjektivitas pengamat pada penentuan ketinggian kompartemen. Penelitian ini bertujuan untuk menanggulangi kelemahan tersebut sehingga didapatkan nilai koreksi terrain yang lebih akurat. Pada penelitian ini estimasi koreksi terrain dilakukan dengan metode square pattern dan sloped triangle. Metode ini membagi daerah di sekitar titik pengukuran menjadi zona berisi kompartemen berbentuk persegi dan segitiga. Penelitian dimulai dengan uji coba program perhitungan koreksi terrain dengan data sintetik, untuk melihat pengaruh tubuh batuan pada koreksi terrain. Selanjutnya program diaplikasikan pada data Karangsambung untuk melihat pengaruh topografi di sekitar Karangsambung terhadap nilai koreksi terrain. Kemudian program diaplikasikan pada data gayaberat, dan dibandingkan hasilnya dengan perhitungan menggunakan Hammer chart. Berdasarkan uji coba data sintetik, didapat bahwa nilai koreksi terrain dari tubuh batuan berukuran $10 \times 10 \mathrm{~km}$ dengan beda tinggi $1000 \mathrm{~m}$ dari stasiun, tidak lagi berpengaruh secara signifikan di jarak $20 \mathrm{~km}$. Topografi di sekitar Karangsambung berupa Pegunungan Serayu Selatan dengan ketinggian 1000 m pada jarak $2030 \mathrm{~km}$ memberikan pengaruh sebesar $0.05 \mathrm{mGal}$ terhadap koreksi terrain, sedangkan Gunungapi Kuarter dengan ketinggian 3000 m pada jarak $3040 \mathrm{~km}$ memberikan pengaruh sebesar 0.1 mGal. Hasil penerapan pada data gayaberat menunjukkan bahwa penggunaan metode square pattern dan sloped triangle mampu mengkoreksi kesalahan dari Hammer chart sampai dengan $3 \mathrm{mGal}$. Selisih perhitungan kedua metode ditemukan semakin besar di daerah lereng, hal ini dikarenakan estimasi beda ketinggian topografi di lereng sulit untuk dilakukan.

Kata kunci: Karangsambung, koreksi terrain, square pattern, sloped triangle

\section{PENDAHULUAN}

Perhitungan koreksi terrain secara konvensional dilakukan dengan menghamparkan kertas transparan berisi Hammer 
chart di atas sebuah peta topografi, kemudian ketinggian rata-rata setiap kompartemen diestimasi. Prosedur ini memiliki kelemahan, yaitu jumlah kompartemen yang relatif sedikit untuk daerah dengan variasi topografi yang besar, dan adanya subjektifitas pengamat pada penentuan ketinggian rata-rata kompartemen (Nowell, 1999). Contoh praktis dari metode Hammer chart diterapkan sampai saat ini pada kuliah lapangan Karangsambung Teknik Geofisika ITB. Pembagian zona pada Hammer chart disimplifikasi menjadi empat kompartemen berbentuk segmen cincin konsentris dengan radius dalam 2 meter dan radius luar 100 meter. Beda tinggi kompartemen terhadap ketinggian stasiun diestimasi secara visual di lapangan.

Penerapan simplifikasi metode ini dapat menimbulkan kesalahan. Penyebabnya pertama adalah karena kondisi topografi di sekitar Karangsambung relatif bervariasi. Berdasarkan Bemmelen (1949), daerah Karangsambung berada di satuan fisiografi Pegunungan Serayu Selatan dengan beberapa titik tertingginya mencapai lebih dari 1000 meter. Di sebelah barat laut dan timur laut juga terdapat topografi tinggi berupa gunungapi kuarter yang mencapai $3000 \mathrm{~m}$ yaitu Gunung Slamet, Gunung Sumbing dan Gunung Sindoro. Illustrasi fisiografi daerah Karangsambung dapat dilihat pada Gambar 1. Penyebab kedua adalah penentuan beda ketinggian secara visual bergantung pada subjektifitas pengamat. Penyebab ketiga adalah radius perhitungan koreksi terrain yang sempit. Untuk menghitung nilai koreksi terrain secara maksimal, dibutuhkan pengukuran beda ketinggian dengan radius cincin pengukuran yang lebih besar, namun perhitungan koreksi terrain secara konvensional akan memakan waktu yang lama dan tidak mungkin dilakukan selama kuliah lapangan berlangsung.

Saat ini metode perhitungan koreksi terrain telah berkembang Beberapa diantaranya adalah, Kane (1962) menyajikan sebuah penelitian mengenai perhitungan koreksi terrain menggunakan komputer. Pada penelitian tersebut ia membuat sistem perhitungan koreksi terrain dengan membagi daerah menjadi grid. Nagy (1966) memaparkan pada penelitiannya mengenai aplikasi metode pendekatan body batuan prisma pada koreksi terrain. Terdapat pula penelitian perhitungan koreksi terrain dengan memanfaatkan data satelit, seperti pada penelitan yang dilakukan Almeida dkk. (2018). Pada penelitian tersebut topografi daerah diambil dari data DEM (Digital Elevation Model) dan perhitungan koreksi terrain dilakukan dengan menggunakan perangkat lunak Matlab.

Pada penelitian ini, penulis mencoba untuk membuat desain program perhitungan koreksi terrain yang mampu menanggulangi kelemahan dari prosedur perhitungan koreksi terrain konvensional. Perhitungan dilakukan dengan menggunakan metode square pattern dan sloped triangle. Program ini diaplikasikan pada daerah Karangsambung untuk melihat pengaruh topografi terhadap nilai koreksi terrain di area penelitian. Selanjutnya program diaplikasikan pada data gayaberat kuliah lapangan Karangsambung, untuk membandingkan hasil perhitungan CBA (Complete Bouguer Anomaly) berdasarkan perhitungan koreksi terrain metode Hammer chart yang disimplifikasi, dengan perhitungan berdasarkan metode square pattern dan sloped triangle.

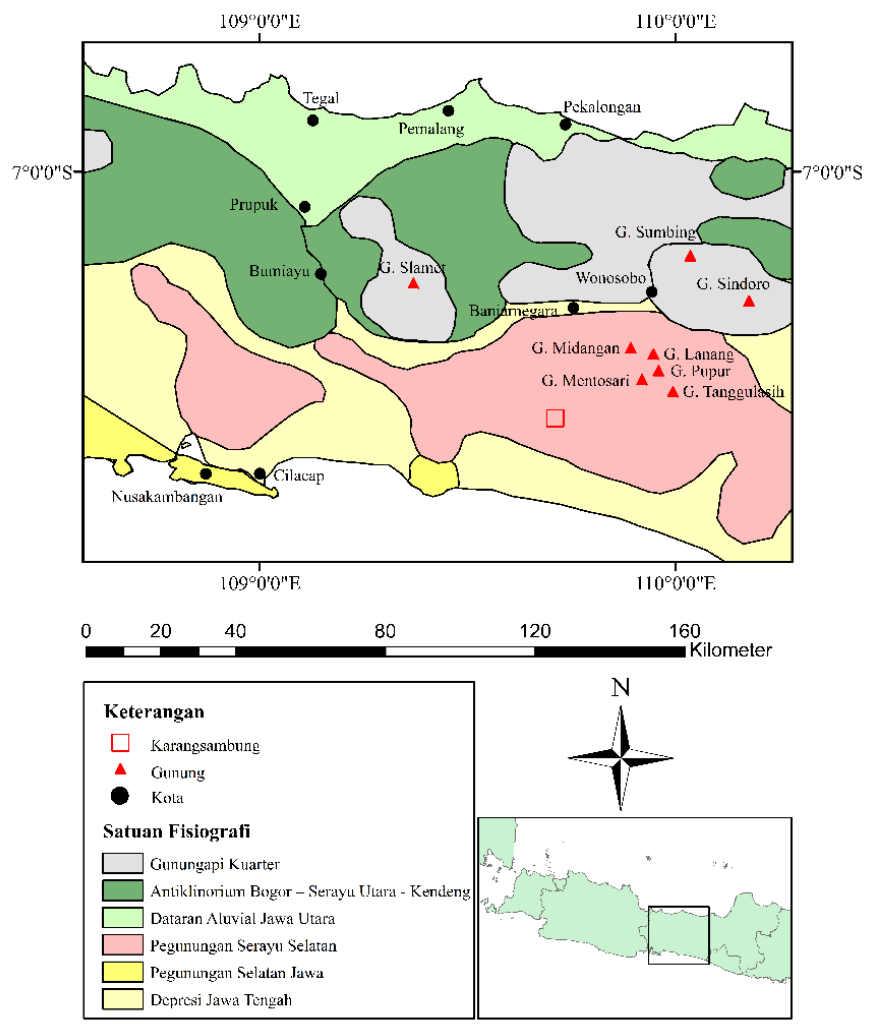

Gambar 1. Fisiografi regional Jawa Tengah (Bemmelen, 1949).

\section{DATA DAN METODOLOGI}

\subsection{Data}

Data yang digunakan pada studi ini adalah data topografi dan gayaberat. Data topografi berasal dari model elevasi SRTM (Shuttle Radar Topography Mission) tahun 2012, dengan resolusi 3 arcsecond atau sekitar $90 \mathrm{~m}$, meliputi wilayah berukuran $103 \mathrm{~km}$ x $103 \mathrm{~km}$, dengan pusatnya adalah area Karangsambung. Sedangkan data gayaberat yang digunakan merupakan hasil pengukuran kuliah lapangan Karangsambung Teknik Geofisika ITB tahun 2018.

\section{$2.2 \quad$ Metodologi}

Pada perhitungan koreksi terrain menggunakan metode square pattern dan sloped triangle, area dibagi menjadi kompartemen. Pola pembagian area memiliki konsep yang sama dengan pembagian Hammer chart, di mana setiap kompartemennya diwakilkan dengan satu nilai ketinggian. Perbedaan terdapat pada kompartemennya yang berpola persegi (square pattern) dan segitiga (sloped triangle). Pada metode ini tubuh batuan didekati dengan bentuk prisma segiempat yang dipublikasikan oleh Plouff (1976), dan sloped triangle yang dipublikasikan oleh Kane (1962). 


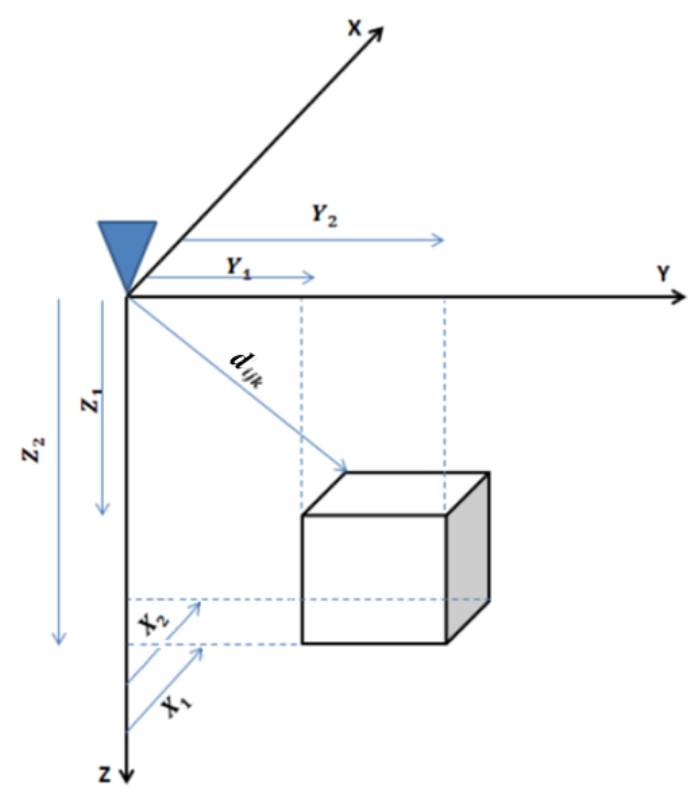

Gambar 2. Pendekatan tubuh batuan dengan prisma segiempat (Plouff, 1976).

Perumusan gayaberat arah vertikal untuk pendekatan tubuh batuan prisma segiempat adalah sebagai berikut:

$$
\begin{array}{r}
g_{(x, y, z)}=G \rho \sum_{i=1}^{2} \sum_{j=1}^{2} \sum_{k=1}^{2} s_{i j k} \times\left[z_{k} \tan ^{-1} \frac{x_{i} y_{j}}{z_{k} r_{i j k}}\right. \\
-x_{i} \ln \left(r_{i j k}+y_{j}\right)-y_{j} \ln \left(\left(r_{i j k}+x_{i}\right)\right] \\
d_{i j k}=\sqrt{x_{i}^{2}+y_{j}^{2}+z_{k}^{2}}, \\
\mu=(-1)^{i}(-1)^{j}(-1)^{k}
\end{array}
$$

dengan G merupakan konstanta, $\rho$ merupakan densitas batuan, $d_{i j k}(\mathrm{~m})$ adalah jarak titik $x_{i}, y_{j}, z_{k}, x$ adalah komponen sumbu $x$ dari jarak titik pengukuran ke tiap sudut prisma, $y$ adalah komponen sumbu $y$ dari jarak titik pengukuran ke tiap sudut prisma, dan $z$ adalah komponen vertikal dari jarak titik pengukuran ke tiap sudut prisma. Ilustrasi dari prisma segiempat dapat dilihat pada Gambar 2.

Perhitungan body batuan sloped triangle berdasarkan hasil penelitian Kane (1962) diilustrasikan pada Gambar 3. Berikut ini adalah persamaannya:

$$
g=G \rho \phi\left(A-\sqrt{A^{2}+h^{2}}+\frac{h^{2}}{\sqrt{A^{2}+h^{2}}}\right.
$$

dengan $\mathrm{G}$ merupakan konstanta gravitasi, $\rho$ merupakan densitas batuan, $\phi$ (rad) adalah sudut bukaan alas sloped triangle, $A(\mathrm{~m})$ adalah sisi miring alas sloped triangle, $h(\mathrm{~m})$ adalah ketinggian sloped triangle.

Pola pembagian daerah dapat dilihat pada Gambar 4. Daerah di sekitar titik pengukuran akan dibagi menjadi grid berbentuk persegi. Daerah dibagi menjadi dua zona yaitu near zone dan intermediate zone. Near zone mencakup kompartemen lokasi stasiun berada, kompartemen tersebut kemudian dibagi menjadi empat segitiga dan perhitungan koreksi terrainnya menggunakan pendekatan sloped triangle.

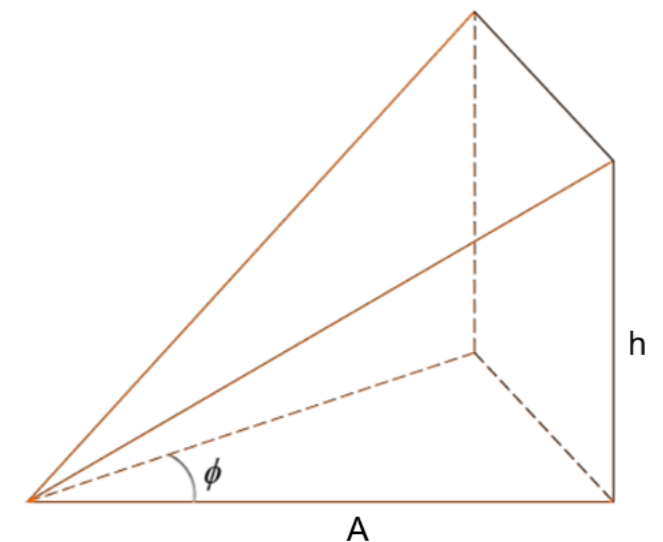

Gambar 3. Pendekatan tubuh batuan dengan sloped triangle (Kane, 1962).

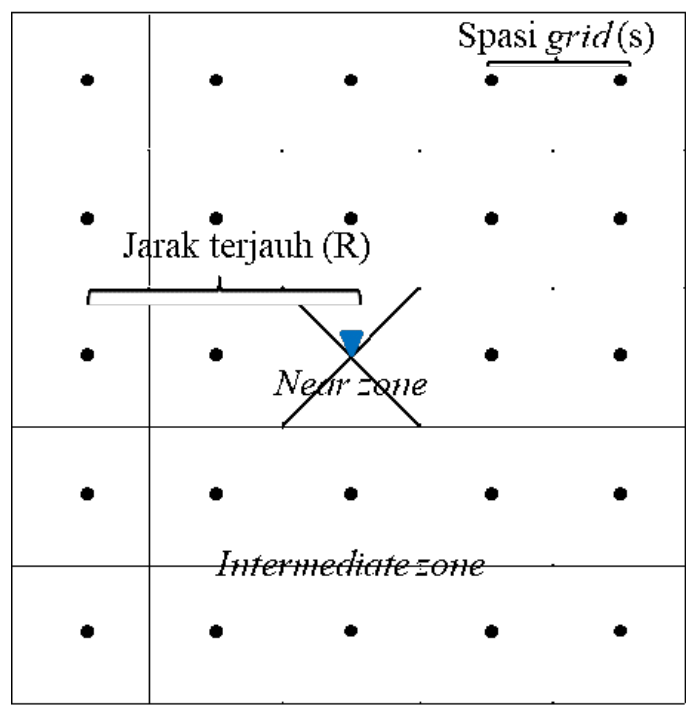

$\checkmark$ Stasiun

- Pusat kompartemen

Gambar 4. Pola pembagian daerah di sekitar stasiun.

Sementara intermediate zone mencakup semua kompartemen kecuali kompartemen near zone dan perhitungan koreksi terrainnya menggunakan pendekatan prisma segiempat. Ketinggian setiap kompartemen diwakili oleh satu nilai ketinggian yang merupakan ketinggian titik tengah dari kompartemen. Kompartemen tersebar ke arah utara, timur, selatan dan barat sejauh $\mathrm{R}$ dari stasiun, dengan spasi s. Jumlah kompartemen menyesuaikan dengan nilai $\mathrm{R}$ dan $\mathrm{s}$ yang dimasukkan.

Pada penelitian ini terdapat beberapa tahapan. Pertama dilakukan uji coba menggunakan data sintetik untuk melihat pengaruh jarak terhadap nilai koreksi terrain dari tubuh batuan yang besar. Tahap kedua uji coba dilanjutkan dengan menggunakan data topografi Karangsambung untuk melihat pengaruh topografi di sekitar Karangsambung terhadap nilai koreksi terrain di area penelitian. Tahapan terakhir adalah mengaplikasikan program pada data gayaberat 

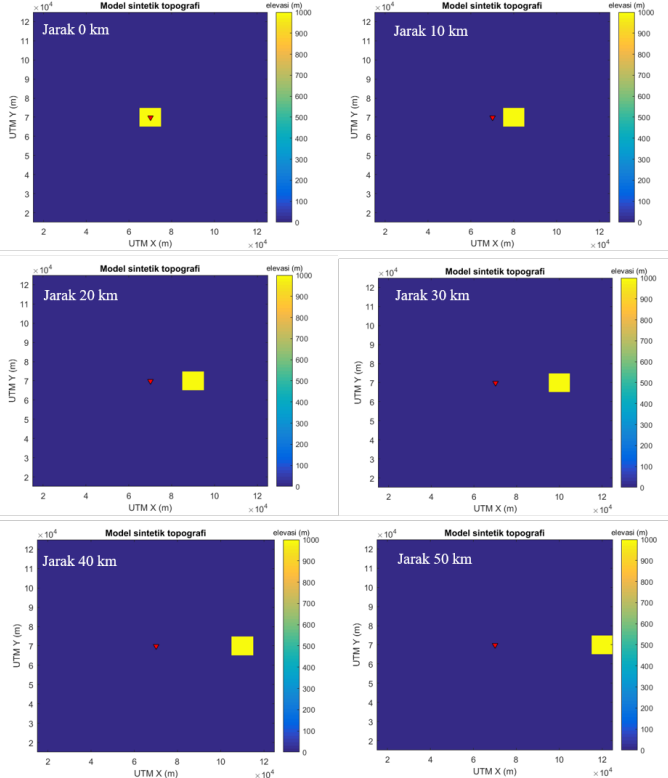

Gambar 5. Data sintetik untuk melihat pengaruh beda elevasi yang besar pada berbagai jarak terhadap koreksi terrain..

kuliah lapangan Karangsambung 2018. CBA hasil reduksi menggunakan koreksi terrain metode square pattern dibandingkan dengan CBA hasil reduksi metode Hammer chart yang disimplifikasi.

\section{HASIL DAN PEMBAHASAN}

Pada uji coba pertama dibuat sebuah tubuh batuan dengan dimensi $10 \times 10 \mathrm{~km}$ dan beda ketinggian terhadap stasiun sebesar $1000 \mathrm{~m}$. Tubuh batuan ini divariasikan jaraknya dari stasiun, mulai dari $0 \mathrm{~km}$ sampai $50 \mathrm{~km}$, dengan interval 10 $\mathrm{km}$. Parameter yang digunakan adalah Jarak terjauh (R) 50 $\mathrm{km}$, spasis grid (s) $10 \mathrm{~km}$, dan densitas batuan $2700 \mathrm{~kg} \mathrm{~m}-3$. Ilustrasi tubuh batuan dapat dilihat pada gambar 5 .

Gambar 6 menunjukkan nilai koreksi terrain dari batuan pada berbagai jarak. Hasilnya mengindikasikan pada jarak $20 \mathrm{~km}$ nilai koreksi terrain sudah relatif menuju 0 . Berdasarkan hal tersebut dapat disimpulkan bahwa tubuh batuan dengan dimensi tersebut sudah tidak berpengaruh lagi pada jarak $20 \mathrm{~km}$, sehingga pengukuran koreksi terrain cukup dilakukan sampai jarak $20 \mathrm{~km}$ dari stasiun. Nilai ini cukup dekat dengan batas jarak pengukuran koreksi terrain pada penelitian yang dilakukan oleh Hammer (1939) yaitu $21.9 \mathrm{~km}$.

Tahap kedua menggunakan data topografi yang berasal dari model elevasi SRTM. Peta topografi daerah Karangsambung dan sekitarnya dapat dilihat pada gambar 7. Di sekitar Karangsambung terdapat Pegunungan Serayu Selatan dan Gunungapi Kuarter yang berpotensi memberikan nilai koreksi terrain yang signifikan walaupun jaraknya di atas $20 \mathrm{~km}$.

Untuk mengetahui hal tersebut, diambillah 6 titik uji coba yaitu titik A, B, C, D, E dan F yang memiliki variasi elevasi sekitar $40500 \mathrm{~m}$. ilustrasinya dapat dilihat pada gambar 8.

Masing masing titik dihitung nilai koreksi terrainnya

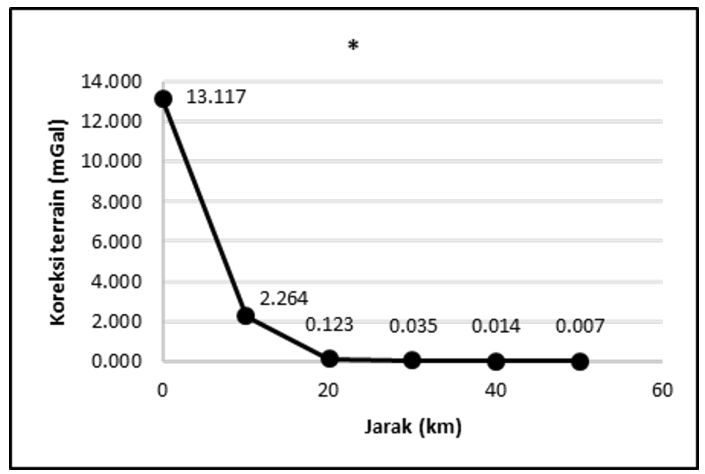

Gambar 6. Nilai koreksi terrain tubuh batuan $10 \times 10 \mathrm{~km}$ pada berbagai jarak.

\section{Peta DEM area $103 \times 103$ km}

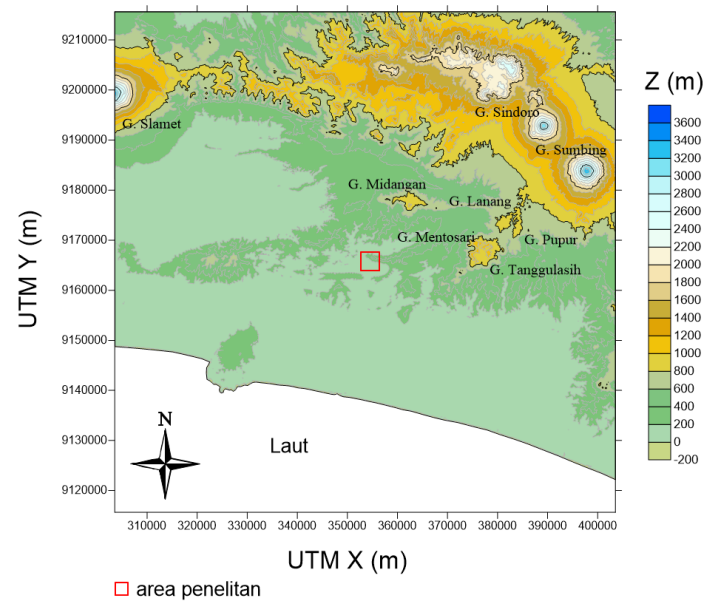

Gambar 7. Peta Topografi daerah Karangsambung dan sekitarnya.

\section{PETA TOPOGRAFI \\ KARANGSAMBUNG}

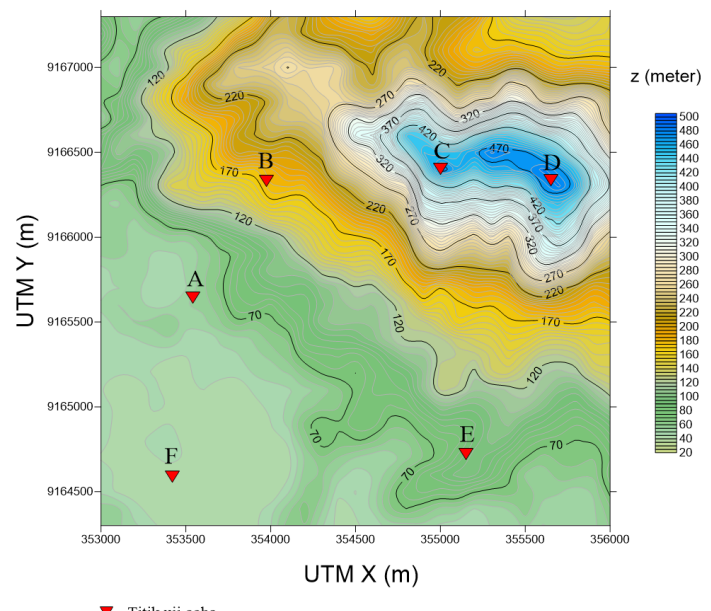

Gambar 8. Persebaran titik uji coba pada area penelitan. 


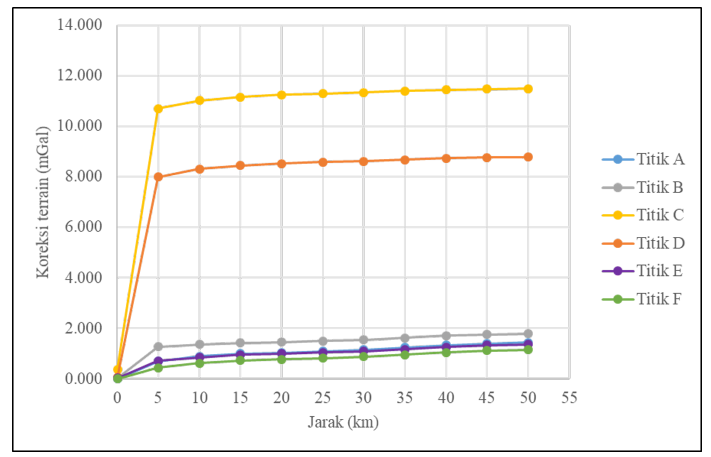

Gambar 9. Nilai koreksi terrain perjarak.

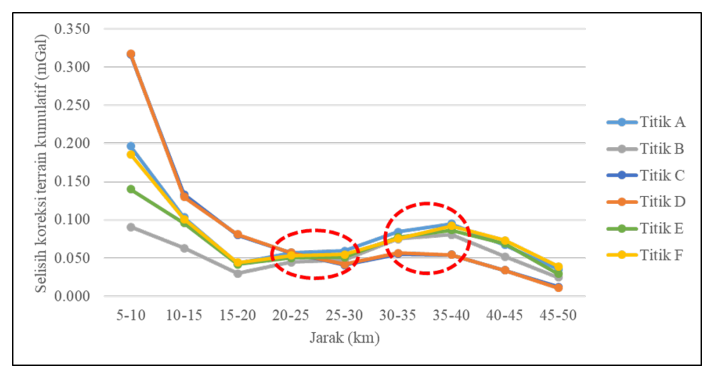

Gambar 10. Selisih nilai koreksi terrain kumulatif perjarak.

kemudian dianalisis kenaikan nilai koreksi terrainnya seiring dengan bertambahnya jarak. Parameter program yang digunakan adalah, besar spasi grid $100 \mathrm{~m}$, dan densitas batuan $2400 \mathrm{~kg} \mathrm{~m}^{-} 3$, nilai ini diambil dari densitas batu lempung yang merupakan penyusun matriks dasar batuan daerah Karangsambung. Hasilnya ditunjukkan pada Gambar 9. Hasil plot menunjukkan setelah jarak $20 \mathrm{~km}$ masih terjadi kenaikan nilai koreksi terrain. Untuk melihat kenaikan dengan lebih jelas, dibuatlah plot jarak terhadap selisih koreksi terrain kumulatif dengan spasi $5 \mathrm{~km}$. Hasilnya disajikan pada Gambar 10.

Hasil perhitungan menunjukkan bahwa selisih koreksi terrain kumulatif akan turun seiring dengan bertambahnya jarak, terkecuali pada jarak $2030 \mathrm{~km}$ dan pada jarak 30 $40 \mathrm{~km}$. Kenaikan pada jarak $2030 \mathrm{~km}$ berasosiasi dengan adanya Pegunungan Serayu Selatan, sementara itu kenaikan pada jarak $3040 \mathrm{~km}$ berasosiasi dengan hadirnya deretan Gunungapi Kuarter. Pegunungan Serayu Selatan di jarak 20 $30 \mathrm{~km}$ dengan ketinggian 1000 m memberikan pengaruh terhadap nilai koreksi terrain berkisar $0.05 \mathrm{mGal}$, sedangkan Gunungapi kuarter di jarak $3040 \mathrm{~km}$ dengan ketinggian $3000 \mathrm{~m}$ berpengaruh berkisar $0.1 \mathrm{mGal}$. Penambahan tersebut dapat dijadikan bahan pertimbangan ketika menentukan jarak terjauh pada perhitungan koreksi terrain.

Pada tahapan terakhir program diaplikasikan pada data kuliah lapangan Karangsambung Teknik Geofisika ITB 2018. Gambar 11 menunjukkan persebaran stasiun.

Estimasi koreksi terrain dilakukan dengan menggunakan dua metode, metode pertama mengestimasi koreksi terrain berdasarkan pengamatan visual di lapangan dengan menggunakan metode Hammer chart yang disimplifikasi, sementara metode kedua mengestimasi koreksi terrain berdasarkan model elevasi SRTM dengan menggunakan

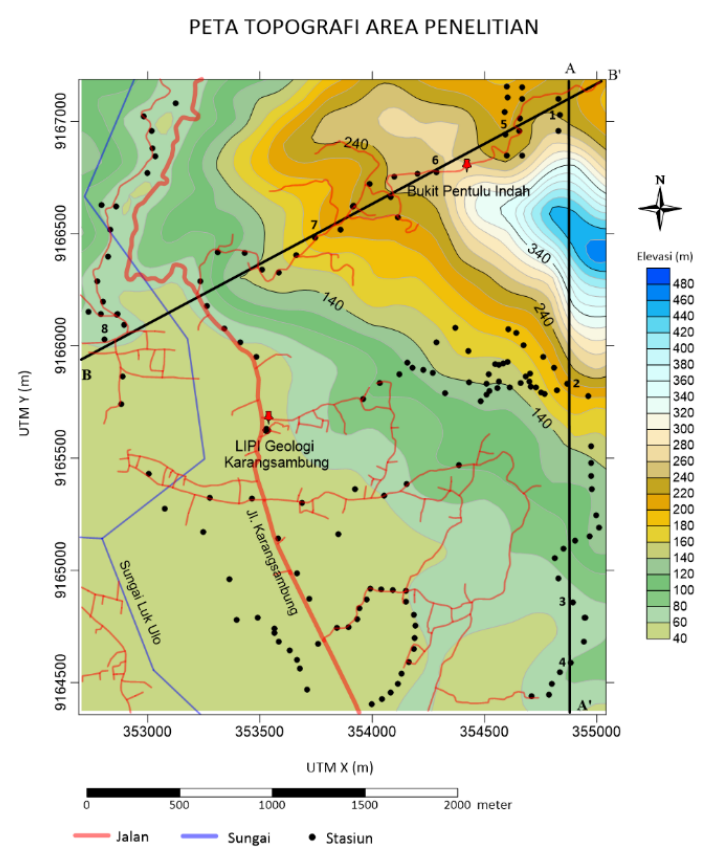

Gambar 11. Persebaran stasiun di area penelitian.

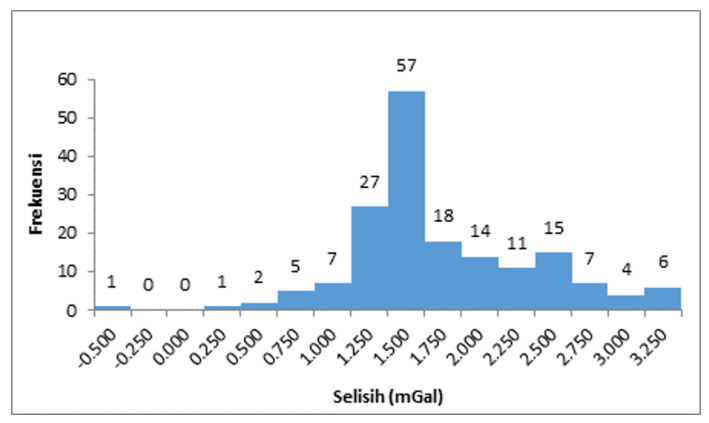

Gambar 12. Histogram selisih TC 2 dan TC 1.

metode square pattern dan sloped triangle. Hasil koreksi metode pertama kemudian disebut sebagai TC 1, dan koreksi metode kedua disebut sebagai TC 2 .

Perbedaan keduanya dianalisis dengan cara melihat selisih TC 2 dan TC 1 (TC 2 TC 1). Hasil yang didapat menunjukkan bahwa nilai TC 2 relatif lebih besar dari TC 1. Dari 175 data yang diambil hanya terdapat 1 data yang memiliki nilai negatif. Nilai selisih bervariasi dari 0.518 sampai dengan 3.176. Histogram data tersebut dapat dilihat pada gambar 12. Berdasarkan hal tersebut, perhitungan dengan menggunakan metode ini mampu mendapatakan nilai koreksi terrain lebih baik dari simplifikasi metode Hammer chart sampai dengan sekitar $3 \mathrm{mGal}$.

Data gayaberat observasi kemudian diolah untuk mendapatkan nilai anomali Bouguer lengkap (CBA). Anomali Bouguer yang diolah menggunakan koreksi terrain TC 1 disebut sebagai CBA 1, sedangkan anomali Bouguer yang diolah menggunakan koreksi terrain TC 2 disebut sebagai CBA 2. Hasil pemetaannya ditunjukkan pada Gambar 13. Terdapat kemenerusan dengan orientasi sama, yaitu berarah timur laut - barat daya dan utara selatan pada kedua 

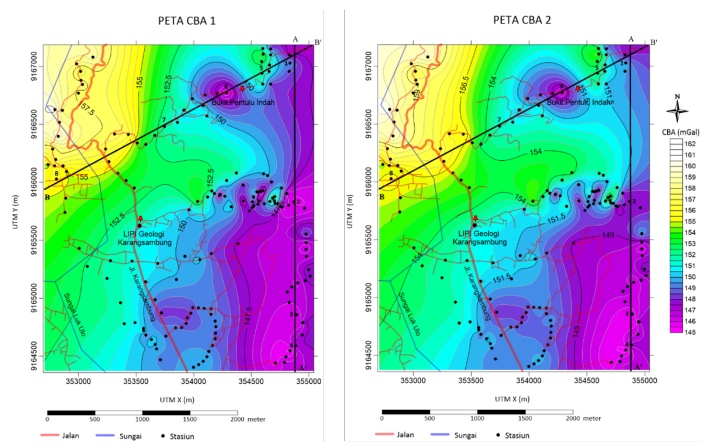

Gambar 13. Peta CBA 1 dan CBA 2.

peta. Perbedaan terdapat pada nilai CBA 2 yang lebih besar dibandingkan dengan CBA 1. Namun dalam pemodelan suatu struktur, nilai tersebut kemungkinan tidak berpengaruh besar kepada model akhir bawah permukaan yang dihasilkan.

Sementara itu apabila ditinjau pada penampang A-A dan B-B, terlihat bahwa selisih CBA 1 dan CBA 2 relatif lebih tinggi pada daerah berelevasi tinggi khususnya di daerah lereng. Penampang A-A dan B-B dapat dilihat pada gambar 14. Pada penampang A-A, proyeksi stasiun 1 dan 2 yang berada di daerah lereng memiliki nilai selisih CBA sekitar $23 \mathrm{mGal}$. Sementara itu proyeksi stasiun 3 dan 4 yang berada pada daerah relatif landai memiliki selisih CBA hanya sekitar $1 \mathrm{mGal}$. Hal serupa ditemukan pula pada penampang B-B. Pada proyeksi stasiun 5 dan 6 selisih CBA berkisar $1.5 \mathrm{mGal}$ sedangkan di proyeksi stasiun 7 dan 8 selisih CBA hanya berkisar $0.5 \mathrm{mGal}$.

Perbedaan selisih CBA kedua metode dapat terjadi karena nilai koreksi terrain bergantung pada variasi topografi di sekitar stasiun. Stasiun yang berada di daerah lereng memiliki variasi topografi yang lebih besar dibandingkan stasiun yang berada di daerah yang landai. Metode simplifikasi Hammer chart bergantung pada pengamatan visual, estimasi beda ketinggian topografi secara visual di sekitar daerah lereng akan jauh lebih sulit dibandingkan dengan estimasi pada daerah yang relatif datar.

\section{KESIMPULAN}

Berdasarkan hasil pengolahan data serta pembahasan, dapat ditarik kesimpulan sebagai berikut, Tubuh batuan berukuran 10 x $10 \mathrm{~km}$ dengan beda elevasi $1000 \mathrm{~m}$ dari stasiun hanya berpengaruh sampai jarak $20 \mathrm{~km}$. Pegunungan Serayu Selatan dengan ketinggan $1000 \mathrm{~m}$ pada jarak 20 $30 \mathrm{~km}$ memberikan pengaruh sebesar $0.05 \mathrm{mGal}$ terhadap koreksi terrain, sedangkan Gunungapi Kuarter dengan ketinggian 3000 m pada jarak $3040 \mathrm{~km}$ memberikan pengaruh sebesar $0.1 \mathrm{mGal}$.

Perhitungan menggunakan metode square pattern dan sloped triangle mampu mendapatkan nilai koreksi terrain lebih baik dibandingkan simplifikasi metode Hammer chart sampai dengan sekitar $3 \mathrm{mGal}$. Peta CBA dengan menggunakan metode square pattern dan metode Hammer chart memiliki kemiripan pola anomali dengan orientasi kemenerusan timur laut - barat daya dan utara - selatan. Selisih perhitungan kedua metode semakin besar pada

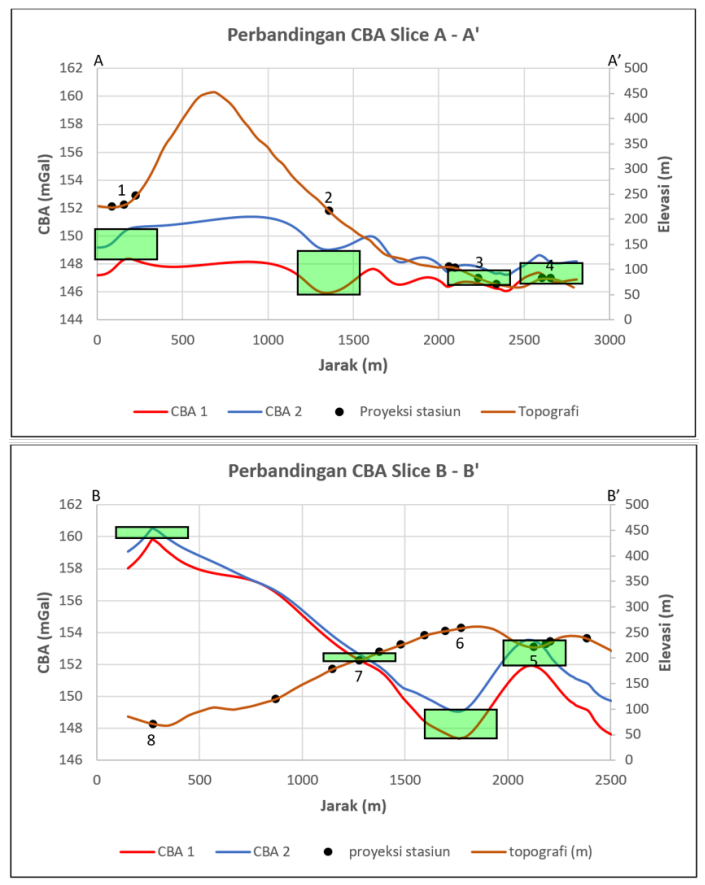

Gambar 14. Penampang A A dan B B.

daerah lereng karena terdapat variasi topografi yang lebih besar, serta estimasi beda ketinggian topografi yang semakin sulit untuk dilakukan.

\section{UCAPAN TERIMA KASIH}

Penulis mengucapkan terimakasih kepada Teknik Geofisika ITB yang telah mendukung selama pengambilan data di Kuliah Lapangan Karangsambung 2018, serta memperkenankan penggunaannya dalam penelitian ini.

\section{DAFTAR PUSTAKA}

Nowell, D. (1999). Gravity terrain corrections an overview.Journal of Applied Geophysics, 42, 117-134.

Bemmelen, V. R. W. (1949). The geology of Indonesia. Martinus Nyhoff, The Haque, Nederland, 28.

Kane, M. F. (1962). A comprehensive system of terrain correction using a digital computer. Geophysics, 27, 455-462.

Nagy, D. (1966). The prism method for terrain correction using digital computers. Pure and applied geophysics, 63, 31-39.

Almeida, F., Lourenco, M., Matias, M., dan Martins, A. (2018). A Matlab script to perform gravity terrain corrections using DEM-EU digital elevation model in a teaching lab. Proc. Conference \& Exhibition Near Surface Geoscience 2018.

Plouff, D. (1976). Gravity and magnetic fields of polygonal prisms and application to magnetic terrain correction. Geophysics, 41, 727-741.

Hammer, S. (1939). Terrain corrections for gravimeter stations. Geophysics, 4, 184-194. 